\title{
PROFILES OF TEACHERS' EXPERTISE AND PROFESSIONAL DEVELOPMENT IN TECHNOLOGY AND ENGINEERING EXPERTISE PROGRAM OF VOCATIONAL SECONDARY SCHOOLS
}

\author{
Istanto Wahyu Djatmiko, Sri Waluyanti, Thomas Sukardi, and Lilik Chaerul Yuswono \\ Faculty of Engineering, Universitas Negeri Yogyakarta, Yogyakarta, Indonesia \\ Email: istanto_wj@uny.ac.id
}

\begin{abstract}
This study was aimed to identify the profiles of teachers' expertise and professional development in Technology and Engineering Expertise Program (TEEP) of Vocational Secondary Schools (VSSs). This study was conducted with a survey approach. The population consisted of 1025 teachers of TEEP at VSSs in Yogyakarta, Indonesia. The samples were 280 teachers selected with proportional random sampling. Data were collected by an open-ended questionnaire and analyzed with a descriptive method. Results of the study identified the profiles of expertise that included the majority of teacher's employment status is government employees and scanty nongovernment employees. The range of working time is mostly from 7 and 18 years. Teachers mostly participate in the teachers' certification through the professional teachers training program. A few number of the teachers have the additional expertise certificates, and none of the teachers has the dual expertise certificates. Furthermore, types of the teachers' professional development activities that followed by most of the teachers are seminars, journals, learning media, and participating as members of teachers association.
\end{abstract}

Keywords: teachers' expertise, teachers' professional development, vocational secondary schools

\section{INTRODUCTION}

Academic qualifications are required for teaching as a profession. As professional workers, teachers need to carry out continuously their skills improvement through professional development for performing their duties more professionally. The government of the Republic of Indonesia has been appreciated teachers as professional workers issued in Law Number 14 Year 2005 regarding Teachers and Lecturers, that stated teachers should have an academic qualification, competence, teachers' certification, physical and mental health, and have the abilities to realize the goals of national education. Academic qualifications that must be met by each teacher was proven by a minimum education level in the form of his or her certificate and or relevant expert certificates in accordance with related laws or regulations [1].

Teacher's academic qualification, especially in Vocational Secondary School
(VSS), must be adjusted to his or her expertise proven by an expertise certificate. This requirement was applied so that each teacher can declare the competency relevant to work expertise respectively. In addition, the teacher's professionalism also needs to be done formally through a teacher's certification. As stated in Law Number 14 Year 2005 that the objectives of teachers' certification were to determine the feasibility of performing their duties as a learning agent in order to realize the goals of national education, to improve the quality of education processes and outcomes, to improve teachers' dignity, to enhance teachers' professionalism, and to increase teachers' welfare [1]. However, in fact, improving teachers' expertise and professionalism still needs to be worked up in its activity qualities and learning process.

According to Mulyasa [2], the teacher's certification was a fulfillment to improve professional competency. The certificate was seen as an essential part of efforts to obtain a 
competency recognition relevant to the appropriated standard. The teacher's certification can also be used as a competency test process for teachers who need to gain their competency recognition in accordance with the occupied profession. The teacher's certification is obtained through two activities forms such as stated in the Regulation of Minister of National Education Number 18 Year 2007 regarding the in-service teacher's certification, namely the teacher's certification obtained through portfolio assessment and the teacher's certification applied through teachers training conducted by the Teacher Training Institute that were accredited and established by the government [3].

Teacher certification was one of the implementation efforts of self-development made to improve the self-professionalism of teachers in order to have the teachers' competency standards that have been established so that they can carry out their main tasks and obligations in learning activities [4]. This statement is similarly expressed by Craft [5]that personal, professional development aimed to improve teachers' skills in their learning and also to provide oversight to schools to clarify the institution policies issued so that school management and improvement more effectively.

Results of Djatmiko's study [6] showed that: (1) some of VSS's teachers $(70.0 \%)$ have followed self-development no more than 4 times, (2) less of VSS's teachers (18.8\%) have conducted scientific publications no more than 2 times, and (3) less of VSS's teachers (16.0\%) have created innovative scientific no more than 3 times during their working as teachers. Based on these data it can be seen the weakness of the professional ability of teachers in VSS. Increasing the teachers' professionalism can also be pursued through additional expertise and dual expertise programs. The additional expertise program is the ability of teachers to be used on different competencies in learning activities, while the dual expertise program is intended to the adaptive program teachers or the normative program teachers who want to be able to teach productive subjects in VSS. It means that the ratio of productive teachers between students and teachers in VSS could be met as expected.

Furthermore, to investigate the above conditions, the objectives of this paper were to identify the teachers' expertise profile, including teachers' status, length of teachers' certification teachers' work, as well as multiple skills and additional expertise of teachers, and to know teachers' professional development, including self-development, scientific publications, innovative works, and VSS Teachers' participation in professional organizations.

\section{METHOD}

This study was a survey study. The population of this study consisted of VSS's teachers of Technology and Engineering Program in Yogyakarta, after this called as Vocational Secondary Schools Teachers (VSSTs). A number of 1025 people with the sample size that was calculated by Krejcie and Morgan formula for 280 people. Samples were distributed with a proportional random sampling technique for each regency and city. Population and samples of VSSTs of each regency and city in Yogyakarta are presented in Table 1.

\begin{tabular}{ccc}
\multicolumn{3}{c}{ Table 1. Population and Samples of VSSTs in Yogyakarta } \\
\hline Regency/ City & Population & Samples \\
\hline Bantul & 149 & 46 \\
Gunungkidul & 250 & 67 \\
Kulon Progo & 180 & 60 \\
Sleman & 211 & 59 \\
Yogyakarta City & 235 & 48 \\
Total & 1025 & 280 \\
\hline
\end{tabular}

Data were collected with an open-ended questionnaire that its validity and reliability were determined by focus group discussions with 
educational experts and practitioners. The questionnaire consisted of 14 aspects, namely: (1) personal identity, (2) school identity (3) educational background, (4) grade and rank (for government employee), (5) teachers' position (for government employee), (6) employee background (for non-government employee), (7) expertise certification, (8) additional expertise certification, (9) dual expertise certification, (10) teaching experience, (11) teacher's self-development, (12) scientific publication, (13) innovative works, and (14) teacher's participation in the expert organization, the scientific forum, or the board of professional vocational teachers.

\section{RESULTS AND DISCUSSION}

This section will describe five profiles results of this study which include the employee status of VSSTs, the length of working time of VSSTs, the teachers' certification, and the additional expertise and the dual expertise of VSSTs in Yogyakarta. The employee status of teachers has been regulated in the Government Regulation Number 48 Year 2005 regarding the assignation of honorary staffs as candidates of government employees that states a teacher is an educator who is appointed by the educational unit organized by the local government and is given his or her salary in accordance with legislation, while the honorary teacher (non-government) is an educator who is levitated by an educational unit organized by the community and is paid based on an employment agreement [7]. Data of VSST's employee status of each regency and city are shown in Figure 1.

The length of the working time of VSSTs in this study was identified into five groups according to Huberman's theory [8], namely: (1) career entry period, 1-3 years, (2) stability period, 4-6 years, (3) divergent period, 7-18 years, (4) second divergent period, 19-30 years, and (5) disengagement period, i.e., up to 50 years in his or profession. These length of working time are closely related to the performance of teachers in carrying out their profession.

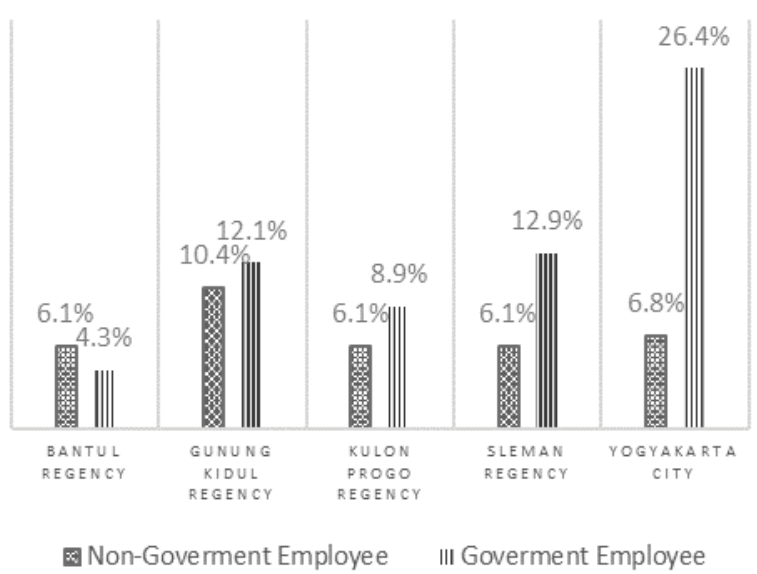

Figure 1. The Employee Status Profile of VSSTs

Some of VSSTs (41.7\%) in Bantul Regency carried out their duties from 7 years to 18 years, and only less of VSSTs (3.4\%) performed their duties from 19 years to 30 years. The longest of working time owned by VSSTs (31\%) was from 0 year to 3 years in the Automotive Expertise Program teachers, and the lowest (3.4\%) was from 19 years to 30 years for Electrical Expertise Program teachers.

Furthermore, some of VSSTs (49.2\%) in Gunungkidul Regency performed their duties from 7 years to 18 years and only small of VSSTs teachers $(4.8 \%)$ performed their duties from 4 years to 6 years. The longest of working time owned by VSSTs (31\%) was from 7 to 18 years in Automotive Expertise Program and the lowest $(3.2 \%)$ was from 4 years to 7 years also for Automotive Expertise Program teachers.

In Kulon Progo Regency, some of VSSTs (49.2\%) carried out their duties from 7 years to 18 years and only small of VSSTs (4.8\%) performed their duties from 4 years up to 6 years. The highest of working time of VSSTs $(31.0 \%)$ in Kulon Progo Regency was from 7 to 18 years in Automotive Expertise Program, and the lowest 
(2.4\%) was from 4 years to 6 years for the Electronics Expertise Program teachers.

In Sleman Regency, some of VSSTs $(37.7 \%)$ implemented their work from 19 years to 30 years and only small of VSSTs (7.5\%) achieved their tasks from 0 years to 3 years. The most extended working hours owned by VSSTS (15.1\%) in Sleman Regency was from 19 years to 30 years in the Automotive Expertise Program and the least of which was $1.9 \%$ from 31 years to 60 years in the Expertise of Electrical, Mechanical, Aircraft, Chemical, and Automotive Programs.

In Yogyakarta city, some of VSSTs (39.8\%) conducted their duties from 7 years to 18 years and just small of VSSTs $(5.4 \%)$ worked their duties from 31 years to 60 years. The highest of working time of VSSTs (16.1\%) in Yogyakarta City was from 7 years to 18 years in Automotive Expertise Program, and the lowest (1.1\%) was 31 years to 60 years for Mechanical expertise Program teachers.

The descriptions of the working experience time of VSSTs for each regency and city showed that most of the phase of working time of VSSTs respectively in Career, Divergent Phase 1, and Divergent Phase 2. The distribution of the working time can be seen in Figure 2.

Figure 2 shows most of VSSTs in Yogyakarta have worked from 7 years to 18 years. $31 \%$ of VSSTs in Bantul Regency worked from 0 to 3 years in the Automotive Expertise Program along with the major of the Motorcycle Competency (17.2\%). The VSSTSs of Gunungkidul Regency have done their jobs from 7 to 18 years in Automotive Expertise Program at the Light Vehicle Competency (28.6\%). The VSSTs of Kulon Progo Regency (26.2\%) have done their duty dominantly from 7 years to 18 years in Automotive Expertise Program especially for the Light Vehicle Competency (26.2\%). The VSSTs of Sleman Regency (15.1\%) have worked from 19 years and 30 years in
Chemical Expertise Program particularly in the Chemical Competency (7.6\%). Finally, in Yogyakarta City, most of VSSTSs (16.1\%) have worked from 7 years and 18 years in the Automotive Expertise Program mainly in the Light Vehicle competency (16.1\%).
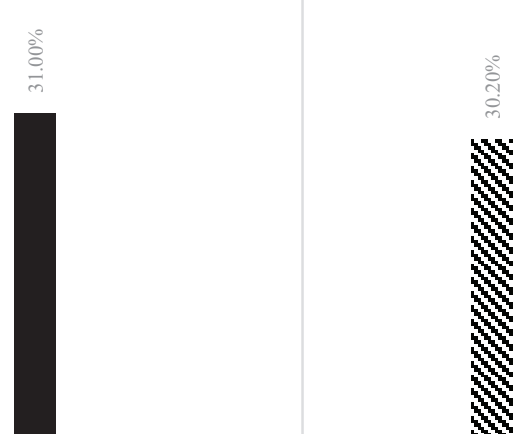

Figure 2. The Length of Working Time of VSSTs in Yogyakarta

Based on the above explanation above, the length of the working time of VSSTs are from 7 years to 18 years. In accordance with Huberman's statement [8], those working time of VSSTs belongs to the category of divergent period meaning that generally, VSSTs can explore and to develop new methods of learning themselves. Furthermore, VSSTs are expected to be able to create competent graduates in accordance with their expertise areas.

Teachers' certification is issued based on the Regulation of the Ministry of National Education Number 11 Year 2011 about the Teachers' Certification, and the Regulation of the Ministry of National Education and Culture Number 29 Year 2016. These decrees contain four kinds of certification implementation for teachers, namely: portfolio assessments, Teacher Professional Training (TPT) or usually called PLPG (Pendidikan dan Latihan Profesi Guru), and the Teacher Professional Education (TPE) that is commonly called PPG (Pendidikan Profesi Guru). 
According to Siagian [9], the purposes of TPT were to improve performance productivity, to encourage self-ability, and to improve job satisfaction. Furthermore, objectives of the Regulation of the Ministry of National Education and Culture Number 87 year 2013 regarding the professional education program for in-service teachers were to produce teacher's candidate who will be competent in planning, implementing, and assessing learning; to guide and to train students after establishing their assessment; be able to have an ability to organize a research and to develop continuously their professionalism [10].

The results of this study show that the teacher's certification of VSSTs primarily obtained through the Portfolio Assessment and the TPT. The implementation of the TPE is currently followed by most of VSSTs who have an undergraduate education background and have not produced TPE graduates right now. Furthermore, teachers who finished a master's degree or a doctoral degree with a minimum grade government employee of IVB will be given the teachers' certificate directly. The detail of the teachers' certification of VSSTSs in each regency and city can be explained as follows.

In Bantul Regency, $41.2 \%$ of VSSTs already have the teachers' certification which most of $24.1 \%$ of Automotive Expertise Program teachers pursued the teachers' certification through the TPT while $3.4 \%$ of VSSTs in Electrical Expertise Programs and Automotive Expertise Programs obtained the teachers' certification through a portfolio assessment.

In Gunungkidul Regency, the teachers' certification map of VSSTs can be seen that most of VSSTs with the percentage of 52.3\% already have the teacher's certification which $15.9 \%$ of Automotive Expertise Program teachers have their certification through TPT, while at least $1.6 \%$ of Electrical Expertise Program teachers obtained through the portfolio assessment.
In Kulon Progo Regency, most of VSSTs with the percentage of $69.1 \%$ already have the teachers' certification. The highest teachers' certification was owned by Automotive Expertise Program teachers with the percentage of $26.2 \%$ through TPT, while at least $2.4 \%$ of Mechanical Expertise Program teachers had both the teacher's certification through the portfolio assessment and the TPT.

In Sleman Regency, the highest teachers' certification is owned by Chemical Expertise Program teachers (18.9\%) through TPT, and at least $3.8 \%$ of Electricity Expertise Program teachers obtained the teachers' certification through the portfolio assessment.

Finally, in Yogyakarta City, most of VSSTs with the percentage of $71.0 \%$ already have teachers' certification which the highest of teacher's certification achieved by Electronic Expertise Program teachers with the percentage of $14.0 \%$ through TPT and at least $1.1 \%$ of Mechanical Engineering and Automotive Engineering expertise program teachers were achieved through the portfolio assessment. The distribution of the teacher's certification of each regency and city can be summarized in Figure 2 .

Figure 3 elaborates more detail of the teachers' certification of the competency program teachers in each expertise programs who obtained the teacher's certification through the TPT. In Bantul regency, the acquisition of the teacher's certification was dominated by most of Light Vehicle Competency Programs with the percentage of $20.7 \%, \quad 12.7 \%$ of the teachers' certifications in Gunungkidul Regency was achieved by Light Vehicle Competency Program teachers, $26.2 \%$ of the teachers' certification in Kulon Progo Regency was owned by Light Vehicle Competency Program teachers, $11.3 \%$ of the teacher's certification in Sleman Regency was attained Chemical Analysis Competency Program teachers, and finally $12.0 \%$ of Audio and Video 
Competency Programs teachers have got the TPT of the teacher's certification in Yogyakarta City.

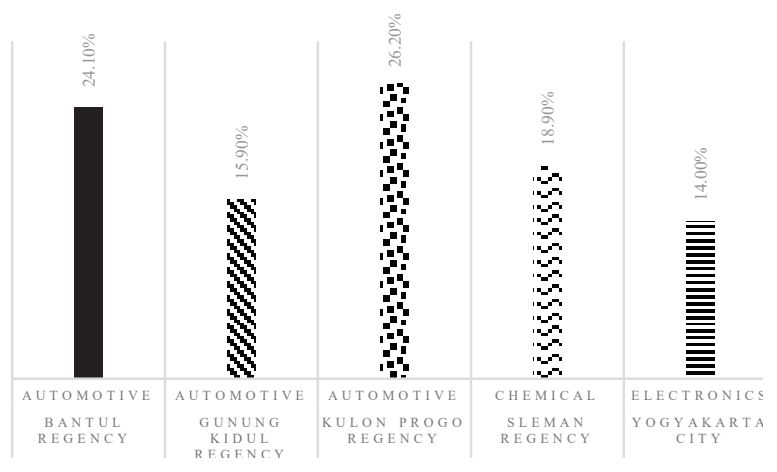

Figure 3. The Teacher's Certification of VSSTs in Yogyakarta

Most of VSSTSs in Yogyakarta have got good abilities, professionalism, and sense to encourage themselves. This result is in line with Siagian's [9] statement that the TPT could improve the productivity, performance, enhancing self-efficacy, and improving job satisfaction. This result also was strengthened by Murwati [11] who stated the teacher's motivation and performance improved after following the TPT.

The teachers' additional expertise was utilized by the VSSTs to support their competency in accordance with their expertise. Five kinds of additional expertise, namely: as an assessor, as an instructor, as both an assessor and an instructor, strengthening the competency to add other competencies which is still in one cluster of the program, and additional skills to increase a competency with different competency but still in one cluster of program. As stated in the Regulation of Ministry Education and Culture Number 12 Year 2017 on Appendix I, the teachers' additional Expertise may be acknowledged with the approval of the province or Regency or city of education authorities in accordance with the authority as national speakers or instructors, facilitators or mentors in teachers' professional development [12].
Furthermore, the dual expertise as written in the Directorate General of Teachers and Education Personnel, Ministry of National Education [13] was transferring and or additional duties of adaptive subject teachers into productive subject teachers of VSS on specific competency in accordance with their interests and talents. The Dual Expertise Program was one of the government policy that issued by the Ministry of Education and Culture in order to overcome the shortage of productive subject teachers in VSS. The profile of Additional and Dual Expertise of VSSTs each regency and city in Yogyakarta are as follows.

The findings shows that the additional expertise of VSSTs in Bantul Regency was conducted as the strengthening competency for most of VSSTs (6.9\%) at Light Vehicle Competency Program. In Gunungkidul Regency, the additional expertise was achieved as assessors (6.3\%) at Light Vehicle Competency Program and a teacher's additional competency approximately (3.20\%) of VSSTSs at Electrical Competency Program. The additional expertise of VSSTs in Kulon Progo Regency was available at most of VSSTSs of Light Vehicle Competency Program with the percentage of $14.3 \%$. In Sleman Regency, the additional expertise was done as teachers' strengthening competency around 7.5\% of VSSTs at Light Vehicle Competency Program. Finally, in Yogyakarta City, the additional Expertise was applied as an assessor with the percentage of $9.7 \%$ at Light Vehicle Competency Program. All in regency and city in Yogyakarta, the dual expertise have not implemented in VSSs yet. Based on the descriptions of the additional expertise and the dual expertise above, it can be stated that both need to be optimized by mapping the needs of VSS productive teachers based on their adequacy and feasibility.

According to Santoso [14], teachers as professions are required to conduct development activities that are directly related to their duties, 
so that teachers can do their job well and student learning facilities can be increased. As explained in Ministry of National Education [4], selfdevelopment was an effort to improve the teachers' professionalism themselves in order to have competency related to legislation so that it can carry out their primary tasks and obligations in learning. Results of this study found three mains self-development activities, namely seminars, workshops, and training. Data of these activities in each regency and city can be explained as follow.

Data of teachers' self-development in Bantul Regency can be seen that most of VSSTs at Automotive Expertise Program followed workshops and seminars with the percentages of $27.6 \%$ and $3.4 \%$ respectively. In Gunungkidul Regency, the teacher's self-development activities were dominantly workshops and seminars at Mechanical Expertise Program with the percentage of $17.5 \%$ and $1.6 \%$ respectively. In Kulon Progo Regency, the teachers' selfdevelopment activities were mostly training of 23.8\% VSSTs at Automotive Expertise Program and seminars at least $2.4 \%$ of VSSTs at Electronics Expertise Program. In Sleman Regency, the teacher's self-development activities were mainly workshops of $15.1 \%$ VSSTs at Chemical Expertise Program and training at least $1.9 \%$ of VSSTs at Aircraft Technology Expertise Program.

The data of teacher's self-development in each regency and city in Yogyakarta concludes that the teachers' self-development activities of VSSTSs in Yogyakarta are still not varied and not evenly distributed. This condition is in line with the statement of Djatmiko's study [6] that many teachers still did not understand the importance of teachers' self-development for improving their professional quality.

In accordance with Agusrida [15], the policy on scientific publication for teachers is expected to provide justice to the profession and grade employee of teachers in accordance with their professionalism. As mentioned in Ministry of National Education [4], the scientific publications were scientific papers published to the public community generally as a part of the teacher's contribution in improving a learning process quality in schools and in developing education quality. There were four kinds of scientific publications which consist of research, journals, national seminar proceedings, and research and journals. The scientific publication data of VSSTSs in each regency and city can be explained as follow.

Types of the teacher's scientific publication in Bantul Regency was journals with the percentage of $3.4 \%$ VSSTs at Automotive Expertise Program. In Gunungkidul Regency, the teachers' scientific publications were journals with the percentage of $3.3 \%$ VSSTSs at Mechanical Expertise Program and national seminar proceedings of $3.3 \%$ VSSTs at Automotive Expertise Program. In Kulon Progo Regency, there were two types of scientific publications, namely national journals and national seminar proceedings. Scientific journals were published by both $2.4 \%$ of VSSTs at Construction and Property Expertise Program of and Automotive Expertise Program, while national seminars were followed by $2.4 \%$ of VSSTs at Automotive Expertise Program. In Sleman Regency, journals were written by $7.5 \%$ VSSTs at Automotive Expertise Program, and at least $1.9 \%$ of VSSTs conducted their research at Mechanical Expertise Program, Chemical Expertise Program, and Automotive Expertise Program respectively. Finally, in Yogyakarta City, journals were also published by $4.4 \%$ of VSSTs at Electrical Expertise Program and at least only $1.1 \%$ of them implemented their research at Chemical Expertise Program. It means that teachers' scientific publications are still being improved in both quantity and quality to write scientific papers. This condition is in line with 
Suwandi's statement [16] that not all teachers did scientific publications so that the teachers' professionalism has not been optimal yet.

As published by the Ministry of National Education [4], the teachers' innovative works were a new development work, a modification or discovery work of teacher's contribution to improve a learning process quality in school and to develop education quality, science and technology, and art. Kind of teachers' innovative works of this study were teaching materials, media, artistry, and online media. Data of these activities in each regency and city can be described as follow.

None of VSSTs produced teachers' innovative works in Bantul Regency and Kulon Progo Regency. In Gunungkidul Regency, 11.1\% of VSSTs at Electricity Expertise Program produced a media and also at least $3.2 \%$ of VSSTs at Electrical Expertise Program developed teaching materials and media. In Sleman Regency, the teachers' innovative works of most of $3.8 \%$ VSSTs at Automotive Expertise Program were teaching materials, and at least $1.9 \%$ of VSSTs at Mechanical Expertise Program produced media. Finally, in Yogyakarta City, teaching materials were developed by $3.4 \%$ teachers of the Automotive Expertise Program and artistries were produced by at least $1.1 \%$ teachers of Mechanical Expertise Program.

Those conditions were expressed by Suwandi [16] that teachers in Indonesia were still relatively less able to develop themselves and tend to consider themselves only as technical personnel. Teachers have difficulties in developing a curriculum into teaching materials and less able to develop a learning media. The teacher's participation in professional organizations or associations was stated clearly by the Ministry of National Education [4] as teachers' collectively activities which suggests the teachers to participate on several scientific meeting activities or joint activities to improve their professionalism. The forms of professional organizations that were affiliated by teachers were the Teachers Association of the Republic of Indonesia which is usually abbreviated as PGRI (Persatuan Guru Republik Indonesia), the forum of teacher's subject matter usually abbreviated as MGMP (Musyawarah Guru Mata Pelajaran), and foundation organizations. The teacher's participation in professional organizations or associations in each regency and city in Yogyakarta can be explained as follow.

Most of VSSTs in Yogyakarta participate mainly in two professional organizations, i.e., PGRI and MGMP. The percentages of VSSTs in Bantul Regency who participate in PGRI and MGMP are $10.8 \%$ and $3.8 \%$ respectively. $39.7 \%$ and $3.2 \%$ of VSSTs are at PGRI and MGMP respectively in Gunungkidul Regency. The teachers' participation in Kulon Progo Regency was distributed in PGRI with the percentage of 23.8\% VSSTs, and in MGMP with the percentage of $31.0 \%$, in the Foundation Organizations were $2.4 \%$ of VSSTs, and in other organizations were $4.8 \%$ of VSSTs. The teachers' participation in Sleman Regency were found $20.8 \%$ of VSSTs in PGRI, 35.8\% of VSSTs in MGMP, and 5.7\% of VSSTs in other organizations. Finally, in Yogyakarta City, $40.9 \%$ of VSSTs participate in PGRI, $19.4 \%$ of VSSTs in MGMP, and $7.5 \%$ of VSSTs in other organizations.

The majority of VSSTs attend PGRI and MGMP, whereas there are other several professional organizations that VSSTs can participate in such as the Teacher Association of Nahdatul Ulama (PERGUNU), Indonesian Teachers Federation (FSGI), and Indonesian Independent Teachers Federation (FGII).

\section{CONCLUSION}

This study identifies the profiles of the VSST's expertise and professional development. The profiles of VSST's expertise include the 
teachers' employee status, the range of working time, the teachers' certification, the additional expertise certificate, and the dual expertise certificate. Furthermore, the VSST's professional development contains the types of selfdevelopment, the form of scientific publications, and the teacher's participation in professional organizations or associations. Most of VSSTs with the percentage of $26.4 \%$ are government employees located in Yogyakarta City, and at least $10.4 \%$ of VSSTs are non-government employees. The range of teachers' working time is mostly from 7 years to 18 years of from $16.1 \%$ to $30.2 \%$ VSSTs, the teachers' certification with the percentage of $26.2 \%$ is prominently obtained by the teacher's professional training program, only less of $9.7 \%$ teachers have an additional expertise certificate, and there is not VSSTs with a dual expertise certificate in all of regency and city in Yogyakarta. The type of self-development that is mostly followed by VSSTs are workshop with the percentage of $27.6 \%$, the form of the teachers' scientific publications that are mostly published by teachers are journals with the percentage of $7.5 \%$, the teachers' innovative works that mostly produced by teachers are learning media with the percentage of $11.1 \%$, and most teachers with the percentage of $40.9 \%$ are as members of the Teachers Association of the Republic of Indonesia.

\section{REFERENCES}

[1] Ministry of National Education, The Law Number 14 Year 2005 regarding Teachers and Lecturers (Undang-undang Nomor 14 Tahun 2005 tentang Guru dan Dosen). Ministry of National Education, 2005.

[2] E. Mulyasa and Mukhlis., Competency Standards and Teacher Certification (Standar Kompetensi dan Sertifikasi Guru). Bandung: Remaja Rosdakarya, 2012.

[3] Ministry of National Education, Regulation of Minister of National Education Number 18 Year 2007 about In-Service Teacher
Certification ( Peraturan Menteri Nasional Republik Indonesia Nomor 18 Tahun 2007 tentang Sertifikasi bagi Guru dalam Jabatan). Ministry of National Education, 2007.

[4] Ministry of National Education, Guidelines for Continuing Professional Development Management, Book 1 (Pedoman Pengelolaan Pengembangan Keprofesian Berkelanjutan, Buku 1. Jakarta: Directorate General of Quality Improvement of Teachers dan Education Personnel.

[5] A. Craft, Continuing Professional Development: A Practical Guide for Teachers and Schools. New York: Routledge, 2002.

[6] I. W. Djatmiko, "A Study on the Empowering Teachers' Professional Development and Quality Assurance to Increase Teachers' Effectiveness in Vocational Secondary Schools," $J$. Pendidik. Teknol. dan Kejuru., vol. 23, no. 2, pp. 144-151, 2016.

[7] Ministry of National Education, Regulation of Government Number 48 Year 2005 Regarding the Appointment of Honorary Personnel Become Candidate of Government Employee (Peraturan Pemerintah Nomor 48 Tahun 2005 tentang Pengangkatan Tenaga Honorer Menjadi Calon Pegawai Negeri Sipil). Ministry of National Education, 2005.

[8] M. Huberman, "Networks That Alter Teaching: Conceptualizations, Exchanges and Experiments," in Teacher Development: Exploring Our Practice (Developing Practice in Primary Education series), London: Paul Chapman Publishing and the Open University, 2001.

[9] S. P. Siagian, Human Resource Management (Manajemen SDM). Jakarta: Bumi Aksara, 1999.

[10] Ministry of Education and Culture, Regulation of the Minister of Education and Culture of the Republic of Indonesia Number 87 Year 2013 Regarding Preparatory Teacher Professional Education Program (Peraturan Menteri Pendidikan dan Kebudayaan Republik Indonesia Nomor 87 Tahun 2013 tentang 
Program Pendidikan Profesi Guru Prajabatan). Ministry of Education and Culture, 2013.

[11] H. Murwati, "Effect of Teacher Profession Certification toward Work Motivation and Teacher Performance in SMK Negeri Surakarta (Pengaruh Sertifikasi Profesi Guru terhadap Motivasi Kerja dan Kinerja Guru di SMK Negeri Se-Surakarta)," J. Pendidik. Bisnis dan Ekon., vol. 1, no. 1, 2013.

[12] Ministry of National Education, Regulation of the Minister of Education and Culture Number 12 Year 2017 on Technical Guidelines for the Distribution of Professional Allowances, Special Allowances, and Supplementary Income of Regional Teachers of Government Employee (Peraturan Menteri Pendidikandan Kebudayaan Nomor 12 Tahun 2017 tentang Petunjuk Teknis Penyaluran Tunjangan Profesi, Tunjangan Khusus, dan Tambahan Penghasilan
Guru Pegawai Negeri Sipil Daerah). Ministry of National Education, 2017.

[13] Ministry of National Education, (Dual Expertise) (Program Sertifikasi Pendidik dan Sertifikasi Keahlian bagi Guru SMK/SMA (Keahlian Ganda). Jakarta: Ministry of National Education, 2017.

[14] D. Santoso, "Need Assessment Pengembangan Keprofesionalan Berkelanjutan Guru SMK Teknik Audio Video," J. Pendidik. Teknol. dan Kejuru., vol. 22, no. 2, pp. 148-154, Oct. 2014.

[15] Agusrida, "Publikasi Ilmiah sebagai Pengembangan Keprofesian Berkelanjutan menuju Guru Profesional," Padang, 2010.

[16] S. Suwandi, "Analysis of Policy Studies of Vocational High School Teacher Management in Order to Improve Education Quality (Analisis Studi Kebijakan Pengelolaan Guru SMK dalam Rangka Peningkatan Mutu Pendidikan)," J. Pendidik. Teknol. dan Kejuru., vol. 23, no. 1, pp. 90-100, 2016. 